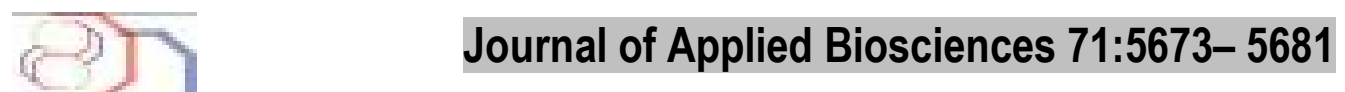

ISSN 1997-5902

\title{
Production of lactic acid from Starchy-based food substrates
}

\author{
*WAKIL Sherifah Monilola and AJAYI, Oluwatoyin Omolara \\ Department of Microbiology, University of Ibadan, Ibadan. \\ Corresponding author email: Shemowak@yahoo.com, +2348034129496
}

Original submitted in on $13^{\text {th }}$ July 2013 Published online at www.m.elewa.org on 30 th November 2013. https://dx.doi.org/10.4314/jab.v71i1.98811

\begin{abstract}
Objective: To determine the best starchy food substrate for the fermentative production of lactic acid. Methodology and Results: Five starchy-based food substrates (maize ogi, sorghum ogi, millet ogi, mashed cassava for gari production and steeped cassava for fufu production) were prepared fresh and allowed to ferment spontaneously for a period of 7 days during which samples of the substrates were subjected to microbiological and chemical analysis. Four growth media were used for the isolation of the different common group of organisms implicated. Yeasts and Molds were identified as Saccharomyces cerevisiae, Candida sp., Aspergillus niger, Aspergillus flavus and Penicillium sp. The bacteria were Lactobacillus plantarum, Lactobacillus casie, Lactobacillus fermentum, Lactobacillus lactis, Klebisella pnemoniae, Escherichia coli, Flavobacterium sp., Proteus vulgaris. The $\mathrm{pH}$ decreased with increase in fermentation time, and it ranged from 3-6 while the total titratable acidity increased within the first 2-3days in cereal-based foods and within the first 45 days in cassava based food substrates, followed by a gradual decrease. Though the lactic acid content fluctuates during the fermentation period, statistical analysis shows that fermentation time has significant effect $(p<0.05)$ on the quantity of lactic acid produced. The two methods (total titratable acidity and spectrophotometric) used to measure the lactic acid content gave similar result of increase within the first 23 days with an intermittent decrease and increase at subsequent days. Statistical analysis revealed that both the method and substrate used has significant effect $(p<0.05)$ on the quantity of lactic acid content produced. Conclusion and application of study: from this study, the steeped cassava produced the maximum lactic acid on the $4^{\text {th }}$ day of fermentation by the two methods used. The results of this study revealed that lactic acid could be produced naturally from steeped cassava. Therefore, the best processing conditions and other optimization parameters should be investigated.

Application of results: The study shows the possibility of Lactic acid biosynthesis using cassava, a low-cost and readily available substrate as source for laboratory/ small scale and eventually large-scale production.

Keywords: Starchy substrates, Fermentation, Lactic acid, Spectrophotometric
\end{abstract}

\section{INTRODUCTION}

Lactic acid is a chemical compound that plays a role in various biochemical processes. It can be produced chemically in the laboratory by mixing two or more chemicals together or by microbial fermentation. The Chemical way of producing lactic acid is rather too expensive and produces racemic mixture of the two forms of lactic acid. Fermentation approach has become more successful because of increasing market demand for naturally produced lactic acid (Narayanan et al., 2004), with an estimated 
worldwide demand of 13,000-15,0000t/year (Wee et al., 2006). To produce lactic acid fermentatively, substrates such as glucose and lactose are used but are rather costly. This necessitated the utilization of cheap agricultural residues as an alternative way to replace costly raw materials and bulk use of such materials will solve environmental hazards (Wee et al., 2005). Studies on lactic acid production from biomass material resources indicated that food wastes rich in starch and oligosaccharide could be an excellent renewable resource as a raw material instead of agricultural products for example potato (Yumiko et al., 2007). However, biomass resources are naturally very complex and heterogeneous in their chemical composition. Therefore, chemical characterization and evolution of the resources potential of each biomass material is necessary. It is essential for an accurate estimation of the fermentable sugars in raw materials and the product (Yumiko et al., 2007). Production of lactic acid is essential because it is used almost in all aspect of human life. It is a widely used chemical that has found application in many industries and various commercial purposes. It is used in leather tanning and textile dyeing and in making inks, solvents and lacquers (Narayanan et al., 2004). Lactic acid is also used in food industry as a preservative, acidulant, and flavouring. The esters of lactic acid are in baking foods as emulsifying agent (Datta et al., 1995; Narayanan et al., 2004). Lactic acid is widely used for inhibiting pathogenic bacteria on animal carcasses like beef, pork, and poultry during

\section{MATERIALS AND METHODS}

Collection of Samples: Grains of maize (Zea mays), sorghum (Sorghum vulgare) and millet (Eleusine coracana), from which the cereal gruels were prepared, were purchased from Bodija Market in Ibadan Metropolis, South Western Nigeria. Cassava tubers used to for 'fufu' and 'gari' production were collected from the Agricultural Research farm, University of Ibadan, Ibadan.

Sample Treatment and Processing: Cereal grains (maize, sorghum, and millet) were handpicked to remove stones, debris, and defective seeds. The grains were steeped in water for 48 hours in clean containers at room temperature $\left(30 \pm 2^{\circ} \mathrm{C}\right)$. The water was decanted and the grains wet-milled. The resulting paste was sieved using sterile muslin cloth and the slurry was allowed to slaughtering process (John et al., 2008). Lactic acid is also used in the chemical industry as raw material for production of lactate ester, propylene glycol, 2,3pentanedione, propanoic acid, acrylic acid, acetaldehyde and dilactide (Varadarajan and Miller, 1999; Akerberg and Zacchi,2000). Lactic acid is also used in pharmaceutical industry as an electrolyte, many parenteral I.V (intravenous) solutions that are intended to replenish the bodily fluids or electrolytes. Example includes lactated Ringer's or Hartmann's solutions CAPD (continuous ambulatory peritoneal dialysis) solution, and dialysis solution for conventional artificial kidney machines. Moreover, lactic acid is used in a wide variety of mineral preparations, which include tablets, prostheses, surgical sutures and controlled drug delivery systems. (Bulletin of the purac, 2012; Bulletin of the Galactic, 2012). Lactic acid offers natural ingredients for cosmetic application. It is primarily used in moisturizers and $\mathrm{pH}$ regulators but they posses multiple other properties such as antimicrobial activity, skin lightening, and skin hydration. Recently, lactic acid consumption has increased considerably because of its role as a monomer in the production of biodegradable poly lactic acid, which is well known as a sustainable bio plastic material (Datta et al., 1995, Litchfield, 1996). In view of the above advantages/ uses of lactic acid from fermentable substrates, this work aimed at producing lactic acid from spontaneously fermenting indigenous starchy based food substrates.

sediment during which spontaneous fermentation was allowed for seven days (Odunfa and Adeyele, 1985). The cassava tubers were peeled, rinsed with distilled water, and divided into two parts. The first portion was diced and steep in sterile distilled water (fufu production) while the second portion was blended and poured into sterile muslin cloth, tied securely and placed on a funnel so that the water drained into a sterile jar. They were left to ferment spontaneously for seven days and each fermented samples were taken daily for the determination of $\mathrm{pH}$, total titratable acidity, lactic acid concentration (spectrophotometrically) and for microbiological analysis. Microbiological Analysis: The number and type of microorganisms per millilitre $(\mathrm{mL})$ of the fermenting 
substrate was estimated daily for seven days by pour plate method using the serial dilution technique. The media used for microbial enumeration were Nutrient agar for estimation of viable aerobic bacteria; de Mann Rogosa and Sharpe (MRS) agar for total lactic acid bacteria incubated at $35 \pm 2^{\circ} \mathrm{C}$ for $48 \mathrm{~h}$ in anaerobic jars; potato dextrose agar (PDA) for moulds counts and yeast extract agar for yeast counts. Potato dextrose agar and yeast extract agar contained $0.5 \mathrm{mg} / \mathrm{l}$ streptomycin sulphate (sigma) incubated at $30^{\circ} \mathrm{C}$ for $3-5$ days.

Chemical Analysis of the fermenting starchy- based food substrates

pH Determination: The $\mathrm{pH}$ of the fermenting substrates was measured daily with the electrode of a $\mathrm{pH}$ metre standardized with the appropriate buffer.

Titratable acidity Determination : The amount of the lactic acid produced in the fermenting starchy- based meal were determine daily for 7 days by the standard titration procedure for total titratable acidity (TTA) according to A.O.A.C, (1990) . Lactic acid content determination was done by titrating $25 \mathrm{ml}$ of the supernatant fluid of the substrates on addition of 3 drops phenolphthalein as indicator, $0.1 \mathrm{M}$ Sodium hydroxide $(\mathrm{NaOH})$ was slowly added from a burette into the samples until a pink colour appeared. Each $\mathrm{ml}$ of $0.1 \mathrm{M} \mathrm{NaOH}$ is equivalent to $90.08 \mathrm{mg}$ of lactic acid.

Total titratable acidity of lactic acid $(\mathrm{mg} / \mathrm{ml})$

$=\mathrm{ml} \mathrm{NaOH} \times \mathrm{N} \mathrm{NaOH} \times$ M.E

Volume of sample used

Where, $\mathrm{ml} \mathrm{NaOH}=$ Volume of $\mathrm{NaOH}$ used,

$\mathrm{N} \mathrm{NaOH}=$ Molarity of $\mathrm{NaOH}$ used,

$\mathrm{M} . \mathrm{E}=$ Equivalent factor $=90.08 \mathrm{mg}$.

Spectrophotometric Determination of Lactic acid: Determination of lactic acid produced was also done

\section{RESULTS}

The yeast count in cereal based fermented foods increases throughout the fermentation period with no growth observed on the 7 th day of fermentation of millet while it increases within the first 3 - 4 days in cassava using spectrophotometric method (A.O.A.C, 1975). $1 \mathrm{ml}$ of sample was pipette into a $100 \mathrm{ml}$ beaker, $25 \mathrm{ml}$ of distilled water was added and neutralized with $1 \mathrm{~N} \mathrm{NaOH}$ using phenolphthalein, $50 \mathrm{ml}$ ether was added, mixed well and centrifuged at 1500rpm for 15 mins, the ether layer was siphoned out into another $100 \mathrm{ml}$ beaker and $20 \mathrm{ml}$ water was added, placed on a steam bath to expel all the ether. The beaker was removed from the steam bath and $6.6 \mathrm{ml}$ of $0.1 \mathrm{~N} \mathrm{Hydrochloric} \mathrm{acid}(\mathrm{HCl})$ was added from burette. Fifty (50) $\mathrm{ml}$ distilled water was added followed by the addition of a high grade DarcoG60 carbon and was mixed thoroughly on a steam beaker for 10 mins. This was cooled with water at room temperature and filtered quantitatively through a Whatman number 2 filter paper. Ten (10) ml filtrate was pipetted into a $50 \mathrm{ml}$ volumetric flask and $5 \mathrm{ml}$ of $1 \%$ ferric chloride solution was added and was made up to volume with distilled water. Standard lactic acid of range $0-5 \mathrm{ppm}$ were prepared from $100-\mathrm{ppm}$ stock lactic acid solution and treated as above. The absorbance of samples as well as standards was measured against blank at a wavelength of $350 \mathrm{~nm}$ on a spectronic 20 spectrophotometer.

mg lactic acid per $100 \mathrm{~g}=\underline{\mathrm{C}(\mathrm{mg} / 100 \mathrm{~g}) \times A \times \text { d.f }}$ Aav

$\mathrm{C}=$ concentration of standard lactic acid $(\mathrm{mg} / 100 \mathrm{~g})$

$A=$ Absorbance of sample

d.f $=$ dilution factor

Aav $=$ Average absorbance of standard

Statistical Analysis: The means and standard deviations of all the data generated after the analyses were calculated. The results were subjected to Duncan multiple range test and significance was accepted at $p<0.05$ among the sample values.

based fermented foods and decreases thereafter. The counts ranges from $1.0 \times 10^{3} \mathrm{Cfu} / \mathrm{ml}$ to $2.5 \times 10^{12} \mathrm{Cfu} / \mathrm{ml}$ in cereal based foods while it ranges from $2.0 \times 10^{3}-1.5 \times$ $10^{\circ} \mathrm{Cfu} / \mathrm{ml}$ in cassava based foods (Table1).

Table 1: Yeast Count (cfu/ml) estimated during spontaneous fermentation of starchy-based food substrates.

\begin{tabular}{|l|l|l|l|l|l|l|l|l|}
\hline Substrates & \multicolumn{7}{l|}{ Fermentation Time (Days) } \\
\hline Code & $\mathbf{0}$ & $\mathbf{1}$ & $\mathbf{2}$ & $\mathbf{3}$ & $\mathbf{4}$ & $\mathbf{5}$ & $\mathbf{6}$ & $\mathbf{7}$ \\
\hline $\mathrm{Y}$ & $1.0 \times 10^{3}$ & $5.0 \times 10^{3}$ & $3.0 \times 10^{6}$ & $7.0 \times 10^{6}$ & $5.0 \times 10^{7}$ & $4.0 \times 10^{7}$ & $6.9 \times 10^{7}$ & $2.6 \times 10^{10}$ \\
\hline $\mathrm{M}$ & $4.0 \times 10^{3}$ & $1.0 \times 10^{5}$ & $3.0 \times 10^{6}$ & $4.0 \times 10^{6}$ & $4.0 \times 10^{6}$ & $4.1 \times 10^{6}$ & $1.7 \times 10^{7}$ & - \\
\hline $\mathrm{S}$ & $6.0 \times 10^{3}$ & $1.0 \times 10^{6}$ & $1.1 \times 10^{5}$ & $1.1 \times 10^{5}$ & $4.5 \times 10^{7}$ & $1.0 \times 10^{9}$ & $8.0 \times 10^{10}$ & $2.5 \times 10^{12}$ \\
\hline $\mathrm{G}$ & $4.33 \times 10^{4}$ & $1.0 \times 10^{5}$ & $6.0 \times 10^{5}$ & $2.3 \times 10^{5}$ & $5.0 \times 10^{8}$ & $1.0 \times 10^{7}$ & $1.0 \times 10^{7}$ & $3.0 \times 10^{6}$ \\
\hline $\mathrm{F}$ & $2.0 \times 10^{3}$ & $4.7 \times 10^{6}$ & $5.2 \times 10^{8}$ & $1.5 \times 10^{9}$ & $5.4 \times 10^{6}$ & $2.0 \times 10^{6}$ & $2.1 \times 10^{6}$ & $1.1 \times 10^{6}$ \\
\hline
\end{tabular}

Key: Y: Maize Ogi, M: Millet Ogi, S: Sorghum Ogi, G: blended cassava, F: steeped cassava, - : signifies no growth. 
Table 2 shows the microbial load of cultivable mould estimated during the fermentation of the five starchybased food substrates. The mould counts of the spontaneously fermenting starchy foods decreases with increased fermentation time with no visible growth after $4^{\text {th }}$ day except in blended cassava substrate (Sample G) where counts increases within the first $48 \mathrm{hr}$ and later decreases till the $7^{\text {th }}$ day. The highest mould count was recorded in sample $G$ while the least count was observed in sample $S$ throughout the sampling period. Substrate $G$ (mash cassava for 'gari' production) counts ranged from $9.6 \times 10^{5} \mathrm{cfu} / \mathrm{ml}$ to $6.0 \times 10^{10} \mathrm{cfu} / \mathrm{ml}$ with the highest on the $2^{\text {nd }}$ day while for substrate $F$ (steeped cassava for 'fufu' production), the load is from $1.4 \times 10^{1} \mathrm{cfu} / \mathrm{ml}$ to $3.0 \times 10^{5}$ $\mathrm{cfu} / \mathrm{ml}$.

Table 2: Mould Count (cfu/ml) estimated during spontaneous fermentation of starchy-based food substrates.

\begin{tabular}{|l|l|l|l|l|l|l|l|l|}
\hline Substrates & \multicolumn{6}{l|}{ Fermentation Time (Days) } \\
\hline Code & $\mathbf{0}$ & $\mathbf{1}$ & $\mathbf{2}$ & $\mathbf{3}$ & $\mathbf{4}$ & $\mathbf{5}$ & $\mathbf{6}$ & $\mathbf{7}$ \\
\hline $\mathrm{Y}$ & $1.0 \times 10^{3}$ & $1.5 \times 10^{3}$ & $3.0 \times 10^{3}$ & $2.0 \times 10^{2}$ & $5.2 \times 10^{1}$ & - & - & - \\
\hline $\mathrm{M}$ & $1.0 \times 10^{6}$ & $1.0 \times 10^{3}$ & $9.0 \times 10^{2}$ & $1.7 \times 10^{2}$ & - & - & - & - \\
\hline $\mathrm{S}$ & $6.0 \times 10^{4}$ & $4.0 \times 10^{2}$ & $1.3 \times 10^{2}$ & $8.0 \times 10^{1}$ & - & - & - & - \\
\hline $\mathrm{G}$ & $9.6 \times 10^{5}$ & $3.5 \times 10^{7}$ & $6.0 \times 10^{10}$ & $3.0 \times 10^{5}$ & $3.0 \times 10^{9}$ & $4.0 \times 10^{9}$ & $5.0 \times 10^{7}$ & $4.0 \times 10^{7}$ \\
\hline F & $2.0 \times 10^{3}$ & $2.0 \times 10^{5}$ & $3.0 \times 10^{5}$ & $2.0 \times 10^{2}$ & $1.4 \times 10^{1}$ & - & - & - \\
\hline
\end{tabular}

Key: Y: Maize Ogi, M: Millet Ogi, S: Sorghum Ogi, G: blended cassava, F: steeped cassava, - signifies no growth

The microbial load of cultivable aerobic bacteria estimated on nutrient agar medium during the fermentation of starchy-based food substrates showed a gradual increase in the bacterial counts within the first 23 days, followed by a decrease in values until the $7^{\text {th }}$ day (Table 3). Higher count was recorded in samples M (millet 'ogi') and $\mathrm{F}$ throughout the sampling period with highest aerobic bacteria count of $1.5 \times 10^{15} \mathrm{Cfu} / \mathrm{ml}$ recorded in day 2 fermenting sample $M$ and least aerobic load (3.0 $\mathrm{x}$ $10^{5} \mathrm{Cfu} / \mathrm{ml}$ ) observed in unfermented (0 day) sample $\mathrm{F}$ (steeped cassava for 'fufu' production).

Table 3: Aerobic Bacteria Count (cfu/ml) estimated during spontaneous fermentation of starchy-based food substrates.

\begin{tabular}{|l|l|l|l|l|l|l|l|l|}
\hline Substrates & \multicolumn{6}{l|}{ Fermentation Time (Days ) } \\
\hline Code & $\mathbf{0}$ & $\mathbf{1}$ & $\mathbf{2}$ & $\mathbf{3}$ & $\mathbf{4}$ & $\mathbf{5}$ & $\mathbf{6}$ & $\mathbf{7}$ \\
\hline $\mathrm{Y}$ & $6.7 \times 10^{8}$ & $1.1 \times 10^{10}$ & $2.5 \times 10^{10}$ & $1.5 \times 10^{10}$ & $1.0 \times 10^{10}$ & $1.5 \times 10^{10}$ & $4.9 \times 10^{7}$ & $3.0 \times 10^{6}$ \\
\hline $\mathrm{M}$ & $2.8 \times 10^{9}$ & $4.7 \times 10^{15}$ & $1.5 \times 10^{15}$ & $6.4 \times 10^{13}$ & $1.0 \times 10^{12}$ & $3.0 \times 10^{10}$ & $2.5 \times 10^{10}$ & $1.9 \times 10^{10}$ \\
\hline S & $3.0 \times 10^{9}$ & $1.0 \times 10^{10}$ & $1.2 \times 10^{10}$ & $9.8 \times 10^{9}$ & $7.8 \times 10^{9}$ & $6.0 \times 10^{9}$ & $1.0 \times 10^{8}$ & $5.4 \times 10^{7}$ \\
\hline G & $9.6 \times 10^{6}$ & $5.9 \times 10^{8}$ & $6.4 \times 10^{10}$ & $3.0 \times 10^{11}$ & $1.1 \times 10^{10}$ & $3.0 \times 10^{9}$ & $2.1 \times 10^{9}$ & $5.0 \times 10^{8}$ \\
\hline F & $3.0 \times 10^{5}$ & $1.5 \times 10^{9}$ & $2.9 \times 10^{11}$ & $2.1 \times 10^{12}$ & $1.4 \times 10^{11}$ & $1.5 \times 10^{11}$ & $1.3 \times 10^{10}$ & $2.0 \times 10^{9}$ \\
\hline
\end{tabular}

Key: Y: Maize Ogi, M: Millet Ogi, S: Sorghum Ogi, G: blended cassava, F: steeped cassava.

The lactic acid bacteria count increases within the first 23 days of fermentation and later decreases until the $7^{\text {th }}$ day expect for substrate $G$ which increases until day 4(Table 4). The highest lactic acid bacteria counts of $\mathrm{x} 10^{16} \mathrm{Cfu} / \mathrm{ml}$ were recorded in substrates $\mathrm{M}$ and $\mathrm{S}$, and the least count of $3.1 \times 10^{4} \mathrm{cfu} / \mathrm{ml}$ in unfermented sample F. For all the fermenting substrates, the least lactic acid bacteria count was observed on the $7^{\text {th }}$ day except for Steeped cassava for fufu production (substrate F).

Table 4: Total Lactic Acid Bacteria (LAB) count (cfu/ml) estimated during spontaneous fermentation of starchy-based food substrates.

\begin{tabular}{|l|l|l|l|l|l|l|l|l|}
\hline Substrates & \multicolumn{7}{|l|}{ Fermentation Time (Days) } \\
\hline Code & $\mathbf{0}$ & $\mathbf{1}$ & $\mathbf{2}$ & $\mathbf{3}$ & $\mathbf{4}$ & $\mathbf{5}$ & $\mathbf{6}$ & $\mathbf{7}$ \\
\hline $\mathrm{Y}$ & $5.0 \times 10^{11}$ & $8.5 \times 10^{11}$ & $1.1 \times 10^{12}$ & $1.3 \times 10^{14}$ & $8.2 \times 10^{11}$ & $8.0 \times 10^{9}$ & $3.0 \times 10^{8}$ & $3.0 \times 10^{7}$ \\
\hline $\mathrm{M}$ & $1.1 \times 10^{14}$ & $1.4 \times 10^{15}$ & $3.3 \times 10^{16}$ & $2.3 \times 10^{16}$ & $1.0 \times 10^{14}$ & $1.0 \times 10^{12}$ & $9.6 \times 10^{9}$ & $4.8 \times 10^{9}$ \\
\hline $\mathrm{S}$ & $2.0 \times 10^{14}$ & $7.7 \times 10^{15}$ & $3.0 \times 10^{16}$ & $1.5 \times 10^{14}$ & $1.7 \times 10^{12}$ & $1.7 \times 10^{12}$ & $2.5 \times 10^{10}$ & $1.9 \times 10^{9}$ \\
\hline $\mathrm{G}$ & $5.6 \times 10^{7}$ & $3.0 \times 10^{9}$ & $1.4 \times 10^{9}$ & $8.0 \times 10^{10}$ & $1.1 \times 10^{11}$ & $5.0 \times 10^{7}$ & $3.0 \times 10^{7}$ & $2.0 \times 10^{6}$ \\
\hline
\end{tabular}




\begin{tabular}{|l|l|l|l|l|l|l|l|l|}
\hline $\mathrm{F}$ & $3.1 \times 10^{4}$ & $2.5 \times 10^{9}$ & $2.9 \times 10^{15}$ & $1.6 \times 10^{14}$ & $1.0 \times 10^{12}$ & $1.0 \times 10^{12}$ & $1.0 \times 10^{11}$ & $8.0 \times 10^{10}$ \\
\hline
\end{tabular}

Key: Y: Maize Ogi, M: Millet Ogi, S: Sorghum Ogi, G: blended cassava, F: steeped cassava.

A total number of 66 isolates consisting of 25 lactic acid bacteria, 15 other bacteria, 17 yeasts and 9 moulds were randomly selected and subcultured from spontaneously fermenting five starchy- based food substrates [maize slurry, sorghum slurry, millet slurry, steeped cassava (for 'fufu' production), and cassava mash (for 'gari' production)] fermented for 7days. The percentage frequency of occurrence is as shown in figure 1 , with lactic acid bacteria having the highest percentage (38\%) of occurrence. The bacterial and yeast isolates were

subjected to various physiological and biochemical tests in order to determine the microbial community of the physiologically active microorganisms. The LAB isolates were identified as Lactobacillus plantarum, Lactobacillus casei, Lactobacillus fermentum, and Lactobacillus lactis. The yeasts isolates were identified as Candida species, Sacharomyces cerevisiae while the moulds were Penicillum species, Aspergillus niger and Aspergillus flavus.

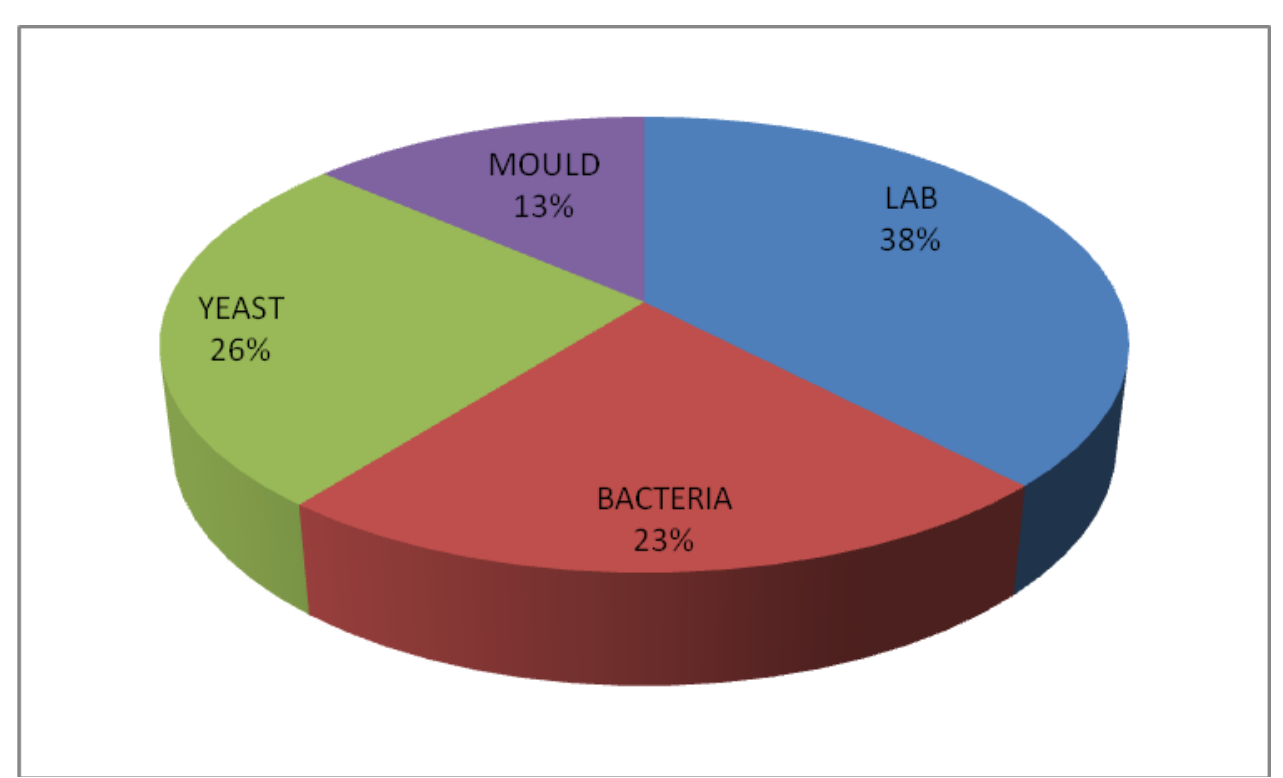

Fig.1: Frequency of occurrence(\%) of the isolated microbial groups

The $\mathrm{pH}$ of the spontaneously fermenting starchy food substrates decreases with increase in fermentation time/day (Table 5). The least acidity was observed in all the unfermented substrates (Oday) while the least $\mathrm{pH}$ was recorded on the $7^{\text {th }}$ day of fermentation. At most, times during sampling, fermenting millet substrate (Sample M) had the least $\mathrm{pH}$ while there was little or no difference in the $\mathrm{pH}$ of fermenting blended cassava (Gari) after day 3 of fermentation. The $\mathrm{pH}$ of all the fermenting substrates ranges from 3.0-6.6.

Table 5: pH of spontaneously fermenting starchy-based food substrates.

\begin{tabular}{|l|l|l|l|l|l|l|l|l|}
\hline Substrates & \multicolumn{7}{l}{ Fermentation Time (Days ) } \\
\hline Code & $\mathbf{0}$ & $\mathbf{1}$ & $\mathbf{2}$ & $\mathbf{3}$ & $\mathbf{4}$ & $\mathbf{5}$ & $\mathbf{6}$ & $\mathbf{7}$ \\
\hline Y & 6.3 & 5.0 & 4.1 & 4.0 & 3.7 & 3.5 & 3.1 & 3.0 \\
\hline M & 5.9 & 5.5 & 3.9 & 3.7 & 3.5 & 3.4 & 3.2 & 3.0 \\
\hline S & 6.5 & 5.0 & 4.5 & 4.4 & 3.7 & 3.4 & 3.3 & 3.1 \\
\hline G & 6.1 & 5.3 & 4.6 & 4.5 & 4.3 & 4.2 & 4.3 & 4.3 \\
\hline F & 6.6 & 5.6 & 5.4 & 4.6 & 3.9 & 3.9 & 3.7 & 3.6 \\
\hline
\end{tabular}

Key: Y: Maize Ogi, M: Millet Ogi, S: Sorghum Ogi, G: blended cassava, F: steeped cassava.

Two methods to compare if there will be differences, to also establish that it is lactic acid produced that was quantified, and not other acid determined the amount of lactic acid produced. Table 6 show the quantification of 
lactic acid produced (total titratable acidity) during the seven days fermentation of the starchy- based food products. From the table, the lactic acid produced increases for all the substrates within the first two days of fermentation, then a fall was observed up till the fourth day followed by a gradual (little) increase except for blended and steeped cassava substrates which had their highest lactic acid production on the first and $4^{\text {th }}$ days of fermentation. The highest total titratable acidity in fermenting substrates $Y$ and $M(7.35 \mathrm{mg} / \mathrm{ml}$ and $6.14 \mathrm{mg} / \mathrm{ml}$ respectively) was observed on the $7^{\text {th }}$ days while the highest lactic acid (TTA) content of $2.77 \mathrm{mg} / \mathrm{ml}$ was recorded for substrate $S$ on the $3^{\text {rd }}$ day. For cassavabased substrates, substrate $G$ had the highest (TTA) lactic acid contents $(7.06 \mathrm{mg} / \mathrm{ml})$ within 24 hours while the highest lactic acid $(10.67 \mathrm{mg} / \mathrm{ml})$ for substrate $F$ (steeped cassava) was on the $4^{\text {th }}$ day. Both substrates ( $F$ and $G$ ) had their least TTA at Ohour. Though the lactic acid content fluctuates during the fermentation period, statistical analysis shows that fermentation time has significant effect $(p<0.05)$ on the quantity of lactic acid produced.

Table 6: Titratable Acidity $(\mathrm{mg} / \mathrm{ml})$ of spontaneously fermenting starchy-based food substrates $\mathrm{pH}$ of spontaneously fermenting starchy-based food substrates.

\begin{tabular}{|c|c|c|c|c|c|c|c|c|}
\hline Substrates & Fermentati & Time (Day & & & & & & \\
\hline Code & 0 & 1 & 2 & 3 & 4 & 5 & 6 & 7 \\
\hline$Y$ & $1.71 \pm 0.20^{a}$ & $3.44 \pm 0.05^{c}$ & $3.75 \pm 0.01^{f}$ & $3.45 \pm 0.01 \mathrm{c}$ & $2.94 \pm 0.02^{b}$ & $3.55 \pm 0.03^{d}$ & $3.62 \pm 0.03 \mathrm{e}$ & $7.35 \pm 0.05 \mathrm{~g}$ \\
\hline$M$ & $1.07 \pm 0.01^{a}$ & $4.24 \pm 0.04 c$ & $5.77 \pm 0.02^{f}$ & $4.51 \pm 0.01^{d}$ & $3.75 \pm 0.02^{b}$ & $4.56 \pm 0.02^{d}$ & $5.06 \pm 0.12^{\mathrm{e}}$ & $6.14 \pm 0.01 \mathrm{~g}$ \\
\hline$S$ & $0.67 \pm 0.02^{a}$ & $1.53 \pm 0.03^{b}$ & $1.78 \pm 0.01^{\mathrm{c}}$ & $2.77 \pm 0.02^{f}$ & $2.06 \pm 0.12^{d}$ & $2.05 \pm 0.05^{d}$ & $2.23 \pm 0.03^{e}$ & $2.16 \pm 0.04$ \\
\hline G & $2.89 \pm 0.01 \mathrm{e}$ & $7.06 \pm 0.12^{h}$ & $2.04 \pm 0.02^{\mathrm{d}}$ & $1.43 \pm 0.01^{c}$ & $3.01 \pm 0.01^{f}$ & $6.40 \pm 0.10 \mathrm{~g}$ & $1.21 \pm 0.03^{b}$ & $0.55 \pm 0.02^{\mathrm{a}}$ \\
\hline $\mathrm{F}$ & $0.54 \pm 0.01^{a}$ & $1.32 \pm 0.01^{b}$ & $4.02 \pm 0.02^{c}$ & $6.65 \pm 0.01^{d}$ & $10.67 \pm 0.03^{h}$ & $8.16 \pm 0.03 \mathrm{e}$ & $9.96 \pm 0.02^{g}$ & $9.30 \pm 0.20^{f}$ \\
\hline
\end{tabular}

Means in each row with different superscripts represent significant difference ( $p \leq 0.05)$ by Duncan Multiple Range Test (DMRT). Values are mean $\pm \mathrm{SD}$, Where SD $=$ Standard Deviation

Using spectrophotometric method, the highest lactic acid contents for all the substrates was observed at different fermentation time (Table 7). Lactic acid contents increases steadily in substrates $Y$ and $M$ till day 3 and fluctuates till the $7^{\text {th }}$ day but similar highest lactic acid contents $(7.35 \mathrm{mg} / 100 \mathrm{ml}$ and $7.37 \mathrm{mg} / 100 \mathrm{ml}$ for substrates $Y$ and $M$ respectively) was observed at different fermentation time while the highest lactic acid content $(9.78 \mathrm{mg} / 100 \mathrm{ml})$ was recorded on the $6^{\text {th }}$ day for substrate $\mathrm{S}$. For cassava based substrates, highest lactic acid content of $17.34 \mathrm{mg} / 100 \mathrm{ml}$ and $16.41 \mathrm{mg} / 100 \mathrm{ml}$ were recorded for substrates $F$ and $G$ respectively. Overall, the highest lactic acid $(17.34 \mathrm{mg} / 100 \mathrm{ml})$ was recorded in substrate $F$ on the $4^{\text {th }}$ day while the least lactic acid content $(3.01 \mathrm{mg} / 100 \mathrm{ml})$ was recorded in unfermented $(0$ day) substrate $M$.

Table 7: Concentration of Lactic Acid (mg/100ml) produced during spontaneous fermentation of starchybased food substrates.

\begin{tabular}{|l|l|l|l|l|l|l|l|l|}
\hline Substrates & \multicolumn{7}{|l|}{ Fermentation Time (Days ) } \\
\hline Code & $\mathbf{0}$ & $\mathbf{1}$ & $\mathbf{2}$ & $\mathbf{3}$ & $\mathbf{4}$ & $\mathbf{5}$ & $\mathbf{6}$ & $\mathbf{7}$ \\
\hline Y & $4.20 \pm 0.02^{\mathrm{c}}$ & $4.57 \pm 0.02^{\mathrm{d}}$ & $4.58 \pm 0.08^{\mathrm{d}}$ & $4.95 \pm 0.06^{\mathrm{e}}$ & $2.97 \pm 0.03^{\mathrm{a}}$ & $3.52 \pm 0.03^{\mathrm{b}}$ & $3.64 \pm 0.16^{\mathrm{b}}$ & $7.35 \pm 0.05^{\mathrm{f}}$ \\
\hline M & $3.01 \pm 0.0^{\mathrm{a}}$ & $3.99 \pm 0.48^{\mathrm{b}}$ & $4.82 \pm 0.14^{\mathrm{c}}$ & $5.82 \pm 0.14^{\mathrm{d}}$ & $4.78 \pm 0.02^{\mathrm{c}}$ & $7.37 \pm 0.03^{\mathrm{f}}$ & $6.78 \pm 0.05^{\mathrm{e}}$ & $4.60 \pm 0.03^{\mathrm{c}}$ \\
\hline S & $5.00 \pm 0.50^{\mathrm{b}}$ & $5.18 \pm 0.02^{\mathrm{b}}$ & $4.37 \pm 0.01^{\mathrm{a}}$ & $6.20 \pm 0.02^{\mathrm{c}}$ & $7.37 \pm 0.02^{\mathrm{d}}$ & $9.16 \pm 0.02^{\mathrm{e}}$ & $9.78 \pm 0.02^{\mathrm{f}}$ & $9.65 \pm 0.03^{\mathrm{f}}$ \\
\hline G & $8.34 \pm 0.04^{\mathrm{a}}$ & $16.41 \pm 0.14^{\mathrm{h}}$ & $7.36 \pm 0.06^{\mathrm{e}}$ & $6.85 \pm 0.14^{\mathrm{d}}$ & $7.75 \pm 0.02^{\mathrm{f}}$ & $6.40 \pm 0.03^{\mathrm{c}}$ & $6.20 \pm 0.03^{\mathrm{b}}$ & $5.60 \pm 0.02^{\mathrm{a}}$ \\
\hline F & $7.78 \pm 0.02^{\mathrm{b}}$ & $10.35 \pm 0.05^{\mathrm{c}}$ & $10.55 \pm 0.05^{\mathrm{d}}$ & $11.35 \pm 0.05^{\mathrm{e}}$ & $17.34 \pm 0.05^{\mathrm{h}}$ & $11.75 \pm 0.10^{\mathrm{f}}$ & $15.55 \pm 0.05 \mathrm{~g}$ & $3.74 \pm 0.04^{\mathrm{a}}$ \\
\hline
\end{tabular}

Means in each row with different superscripts represent significant difference $(p \leq 0.05)$ by Duncan Multiple Range Test (DMRT) Values are mean $\pm S D$, Where SD $=$ Standard Deviation

Table 8 shows the comparison of the concentration of lactic acid produced from each substrate as obtained from the two methods (quantification of lactic acid by total titratable acidity and spectrophotometric) . The range of 
lactic acid content of the total titratable acidity method was from $2.18 \mathrm{mg} / \mathrm{ml}$ for substrate $S$ to $7.23 \mathrm{mg} / \mathrm{ml}$ for substrate $F$. The concentration of lactic acid as recorded from spectrophotometric method showed a very slight difference from the total titratable acidity method. From the two methods of lactic acid determination used, substrate $F$ had the highest lactic acid contents. The least lactic acid content using titratable acidity was recorded in substrate $S(2.18 \mathrm{mg} / \mathrm{ml})$ while the least using spectrophotometric method was observed in substrate $Y$ (maize ogi) which was not significantly different from the lactic acid content of substrate $\mathrm{M}$ (millet ogi). Within each method, the lactic acid content of each fermented starchy substrates were significantly different $(p<0.05)$ from each other except substrates $M$ and $Y$ (spectrophotometric).

Table 8: Comparison of Lactic Acid produced during spontaneous fermentation of the different starchy-based food substrates used.

\begin{tabular}{|l|c|c|}
\hline Substrates Code & Total Titratable Acidity (mg/ml) & $\begin{array}{c}\text { Lactic Acid Concentration } \\
\text { (mg/100ml) }\end{array}$ \\
\hline Y & $4.09 \pm 0.28^{\mathrm{c}}$ & $5.46 \pm 0.70^{\mathrm{a}}$ \\
\hline M & $5.04 \pm 0.01^{\mathrm{d}}$ & $5.80 \pm 0.61^{\mathrm{a}}$ \\
\hline S & $2.18 \pm 0.21^{\mathrm{a}}$ & $7.41 \pm 1.25^{\mathrm{b}}$ \\
\hline G & $3.52 \pm 0.20^{\mathrm{b}}$ & $8.86 \pm 0.73^{\mathrm{c}}$ \\
\hline F & $7.23 \pm 0.32^{\mathrm{e}}$ & $14.06 \pm 0.15^{\mathrm{d}}$ \\
\hline
\end{tabular}

Means in each column with different superscripts represent significant difference $(p \leq 0.05)$ by Duncan Multiple Range Test (DMRT). Values are mean $\pm S D$, Where SD $=$ Standard Deviation

\section{DISCUSSION}

In the study Lactic acid bacteria, yeast, mould and other bacteria associated with the spontaneous fermentation of starchy-based food substrate were isolated and characterised. The Lactobacillus isolates were identified as Lactobacillus plantarum, Lactobacillus casei, Lactobacillus fermentum, and Lactobacillus lactis. The yeasts isolates were identified as Candida species, Sacharomyces cerevisiae. The moulds were Penicillum species, Aspergillus niger and Aspergillus flavus. All of this micro organisms has been reported in previous microbiological studies done on spontaneously fermenting millet 'ogi' (Olasupo et al.,1997), fermenting maize 'ogi'(Ogunbanwo et al., 2003; Wakil and Daodu, 2011), fermenting sorghum 'ogi'(Odunfa and Adeleye, 1985) and fermenting cassava (Kobawila et al., 2005; Oyewole, 1991). The predominant species isolated in the spontaneously fermenting starchy-based food substrates was identified as Lactobacillus casei while Lactobacillus plantarum was second. This is not in support of previous works where Lactobacillus plantarum had been reported to predominate the fermentation. Lactobacillus lactis isolated in this work had been reported to be part of microbial community of starchy-based substrates (Hofvendahl and Hagerdal, 2000, Wakil and Daodu, 2011). Lactic acid count was found to increase within the first three days of fermentation, an observation similar to that of Wakil and Daodu, (2011), and latter decreases until the end of fermentation. A report, similar to that of Nwachukwu et al. (2010). A slight decrease in lactic acid concentration observed in the later stages of fermentation could be attributed to the utilization of lactic acid by yeast (Muyanja et al., 2003). Higher lactic acid bacteria and yeast count was recorded during slurry fermentation, there was a gradual increase in the yeast count all through the fermentation period for all the substrates used as supported by the work of Wakil and Daodu, (2011). This may be because of reduction in $\mathrm{pH}$, which has an inhibitory effect on the growth of some natural micro flora other than lactic acid bacteria and yeast. The predominant yeast during the fermentation period in all the substrates used was Saccharomyces cerevisiae.

The coexistence and symbiotic association between lactic acid bacteria and yeasts in African traditional fermented products have been reported by several authors (Jespersen et al., 1994; Hounhouigan et al., 1993; Omemu et al., 2007). This natural fermentation reduced survival of bacterial pathogens. The inhibitory effects of fermentative organisms, particularly $L A B$, on spoilage and food poisoning organisms are well documented (Inatsu et al., 2004; Schnurer and Magnusson, 2005). The mould count was found to increase gradually all through the period of fermentation in grated cassava for Gari production, an observation similar to that reported in the work of Greenhill et al. (2009). It was observed for all the substrates that $\mathrm{pH}$ decreases during the fermentation period. Similar observation was shown in the works of Achi, (1990), Greenhill et al. (2009) and Nwachukwu et al. (2010). A decrease in $\mathrm{pH}$ as the fermentation progressed 
was possibly because of the accelerated growth rate of lactic acid bacteria (Inyang and Idoko, 2006). The decrease in $\mathrm{pH}$ and increase in LAB followed the same trend as reported for other natural fermented foods (Sulma et al., 1991; Choi et al., 1994). The cause of the increase in acidity and consequent drop in $\mathrm{pH}$ during fermentation of cereal was likely due to utilization of free sugars by yeasts and LAB (Efiuvwevwere and Akona, 1995; Zvauya et al., 1997). The trend in total titratable acidity was directly opposite that observed for $\mathrm{pH}$. There was a gradual increase in total acidity during the first 4 days for steeped cassava; this is in accordance to the work of Tetchi et al., (2012) while the increase within the

\section{CONCLUSION}

From this study, it can be concluded that fermenting cassava, when steeped (submerged fermentation) for 4days or when blended (solid state fermentation) and left

\section{REFERENCES}

AOAC 1975. Association of official Anaytical chemists. (Williams ed.) pg. 254-257.

AOAC 1990. Association of Official Analytical Chemists. Official Methods of Analysis $15^{\text {th }}$ Edition (Helrick, K.ed.). AOAC, Arlington, Virginia.

Achi, O. K. 1990. The potential for upgrading traditional fermented foods through biotechnology. African Journal of Biotechnology 4(5): 375-380,

Akerbeg, C. and Zacchi, G. 2000. An Economic Evaluation of the Fermentative Production of Lactic Acid from Wheat Flour. Journal of Bioresources Technology, 75: 119-126.

Aliya, S. and Geervani, P. 1981. An assessment of the protein quality and vitamin B content of commonly used fermented products of legumes and millets. Journal of Science Food and Agriculture. 32: 837-842.

Bulletin of the Galactic, 2012 (http://www.lactic.com/2012).

Bulletin of the Purac 2012 (http://www.purac.com/2012).

Choi, S., Beuchart, L.R., Perkins, L.M. and Nakayama T 1994. Fermentation and sensory characteristics of kimichi containing potassium chloride as partial replacement of sodium chloride. International Journal of Food Microbiology, 21: 335-340.

Datta, R., Tsai, S.P., Bonsignore, P., Moon, S.H., and Frank, J.R. 1995. Technological and economic potential of poly (lactic acid) and lactic acid derivatives, FEMS Microbiology Rev. 16: $221-$ 231. first 2 days for fermenting maize ogi agrees with the findings of Aliya and Geervani, (1981), Wakil and Daodu, (2011). The total titratable acidity of the fermenting substrates except for substrate $G$ was found to increase within the first two days of fermentation, this result is in agreement with the results of Greenhill et al., (2009). Greenhill et al (2009) recorded a gradual increase in lactic acid concentration up to the $28^{\text {th }}$ day of sago starch fermentation using endogenous microbiota under laboratory conditions. Higher level of lactic acid production during slurry fermentation was because lactic acid bacteria dominated the fermentation, which resulted in reduction in $\mathrm{pH}$ of the fermenting slurry.

to ferment for 1 day produces lactic acid better than fermenting cereals.

Efiuvwevwere, B.J.O., and Akona, O. 1995. The microbiology of kununzaki, a cereal beverage from northern Nigeria during the fermentation (production) process. World Journal of Microbiology and Biotechnology, 11: 491-493.

Greenhill, A. R., Shipton, W.A., Blaney, B.J., Brock, I.J., Kupz, A. and Warner, J.M. 2009. Spontaneous fermentation of traditional sago starch in Papua New Guinea. Food Microbiology, 26: 136-141

Hofvendahl, K., and Hagerdal, B. H. 2000. Factors Affecting the Fermantative Lactic Acid Production from Renewable Resources. Journal of Enzymes and Microbial Technology, 26: 87107.

Hounhouigan, D.J., Nout, M., Nago, C., Houben, J. and Rombouts, F. 1993. Changes in the physicochemical properties of maize during natural fermentation of mawè. Journal of Cereal Science, 17: 291-300.

Inatsu, Y., Bari, M.L., Kawasaki, S. and Isshiki, K. 2004. Survival of Escherichia coli 0157:H7, Salmonella enteritidis, Staphylococcus aureus, and Listeria monocytogenes in Kimchi. Journal of Food Protein, 67: 1497-1500.

Inyang, C.U., and Idoko, C.A. 2006. Assessment of the quality of ogi made from malted millet. African Journal Biotechnology, 5(22): 2334-2337.

Jespersen, L., Halm, M., Kpodo, K. and Jakobsen, M. 1994. Significance of yeasts and moulds occurring in maize dough fermentation for 
'Kenkey' production. International Journal of Food Microbiology. 24: 239-248.

John, R., Nampoothiri, K.M., and Pandey, A. 2008. Fermentative production of lactic acid from biomass: an overview on process developments and future perspectives. Applied Microbiology and Biotechnology, 74: 524-34.

Kobawila, S.C., Louembe, D., Keleke, S., Hounhouigan, J. and Gamba, C.2005. Reduction of the cyanide content during fermentation of cassava roots and leaves to produce bikedi and ntoba mbodi, two food products from Congo. African Journal of Biotechnology, 4 (7):689-696.

Litchfield, J.H. 1996. Microbiological production of lactic acid, Advance Applied Microbiology, 42: 45-95.

Muyanja, C.M., Narvhus, J. A., Treimo, J. and Langsrud, T. 2003. Isolation, characterization, and identification of lactic acid bacteria from bushera: a Uganda traditional fermented beverage. International Journal of Food Microbiology, 80 (3): 201- 210.

Narayanan, N. Roychoudhury, P., and Srivastava, A. 2004. L (+) lactic acid fermentation and its product polymerization. Microbial Biotechnology, I (7): 255-257.

Nwachukwu, E., Achi, O. K., and ljeoma, I. O. 2010. Lactic acid bacteria in fermentation of cereals for the production of indigenous Nigerian foods. African Journal of Food Science and Technology, 1(2): 021-026.

Odunfa, S.A. and Adeyele, S. 1985. Microbiological changes during the traditional production of ogibaba, a West African fermented Sorghum gruel. Journal Cereal Science 3: 173-180.

Ogunbanwo, S.T., Sanni, A.I. and Onilude, A.A. 2003. Influence of cultural conditions on the production of bacteriocin by Lactobacillus brevis OG1. Africa Journal of Biotechnology, 2(7): 179- 184.

Olasupo, N. A., Olukoya, D. K., and Odunfa, S. A. 1997. Assessment of a bacteriocin- producing Lactobacillus strains in the control of spoilage of a cereal-based African fermented food. Folia Microbiology 42:31-34.

Omemu, A.M., Oyewole, O.B., Bankole, M.O. 2007. Significance of yeast in the fermentation of maize for Ogi production. Food Microbiology 24 : 571- 576.

Oyewole, O.B. 1991. Fermentation of cassava for Lafun production. Food Lab. News 17(2): 29-31.

Schnurer, J. and Magnusson, J. 2005. Antifungal lactic acid bacteria as biopreservatives. Trends Food Science and Technology, 16: 70-78.

Sulma, I., Larry, R. S., and Kirlesis, A. 1991.Isolation and characterization of microorganisms associated with the traditional sorghum fermentation for production of Sudanese kisra. Journal of Applied Environmental Microbiology, 57: 2529- 2533.

Tetchi, F. A., Solomen, O.W., Célah, K. A., and Georges, A. 2012. Effect of Cassava Variety and Fermentation Time on Biochemical and Microbiological Characteristics of Raw Artisanal Starter for Attiéké Production. Innovative Romanian Food Biotechnology, 10:50-55.

Varadarajan, S. and Miller, D.J. 1999.Catalytic upgrading of fermentation derived organic acids. Biotechnology Programme, 15: 845-854.

Wakil, S. M., and Daodu, A. A. 2011. Physiological Properties of a Microbial Community in Spontaneous Fermentation of Maize (Zea mays) for Ogi Production. International Research Journal of Microbiology, 2(3): 109-115.

Wee, Y.J., Kim, J.N., and Ryu, H.W. 2006. Biotechnological production of lactic acid and its recent applications. Food Technology and Biotechnology, 44: 163-172.

Wee, Y.J., Yun, J.S., Lee, Y.J., Zeng, A.P., and Ryu, H.W. 2005. Recovery of lactic acid by repeated batch electrodialysis and lactic acid production using electrodialysis wastewater, Journal of Bioscience Bioengineering, 99: 104-108.

Yumiko, J. R., Rombouts F., and Alozon, V. 2007. Recent developments in lactic acid Journal of Applied Bacteriology 69: 609-633.

Zvauya, R, Mygohi, T, and Parawira, S. 1997. Microbial and biochemical changes occurring during production of masvusru and mangisi, traditional Zimbawean beverages. Plant Foods Human Nutrition, 51: 43-51 